\title{
Major challenges for African women theologians in theological education $(1989-2008)^{1}$
}

\author{
Isabel Apawo Phiri ${ }^{2}$ \\ School of Religion and Theology, University of KwaZulu-Natal, Scottsville, \\ Pietermaritzburg, South Africa
}

\section{Abstract}

The aim of this article is to present a critical analysis of how far the Circle of African Women Theologians have addressed the three initial challenges that face African women who are receiving theological education in African theological institutions and to identify new problems. The problem statement of this article is as follows: After nineteen years of the Circle's existence, the African women theologians who constitute the Circle still face the challenges of: self-definition, fewer female student enrolments in theology, poorly represented at academic institutions (few women on staff), resistance to the engendering of the theological curriculum, and lack of greater collaboration with African male theologians in research and publication. The methodology of the article is based on conceptual analysis which, in turn, is based on my personal experiences as a former coordinator of the Circle. I also draw on case studies from Circle partnerships from 2002-2007, and my personal journey in theological education over 24 years in five southern African academic institutions. In conclusion, the article argues that: "After nineteen years of the Circle's existence, African women theologians have gained recognition in the theological arena at both a local and global level. The Circle has achieved its objective of increasing the number of theological publications for the academic use of theological institutions in Africa; it is also participating in theological debates in the northern hemisphere through its partnership of equals with theological institutions. Its ethos of being inclusive in: (1) its definition of African women theologians; (2) its promotion of an increased enrolment of female students and employment of more female staff; (3) its contribution to the process of engendering the theological curriculum in Africa; and (4) its overt efforts to promote collaboration with African male theologians has gone

Studia Historiae Ecclesiasticae, December 2008, 34(2) 63-81 
a long way to show that the Circle is built firmly on the concept of community."

\section{Introduction}

At the IV Congress of the World Conference of Associations of Theological Institutions (WOCATI) from 31 May to 7 June 2008, which was held in Neapolis, Thessalonika, Greece, we were reminded about the new task and role of global ecumenical theological education for the life of the churches and theological institutions in the 21 st century. This conference gave us the opportunity to:

- reconfirm that our primary concern is mission, i.e., the mission of theological education in terms of the churches' mission, and above all, God's mission in today's world. More specifically we explored the reality and the potential of emerging, diverse approaches to theological education in response to the two great threats to life in the twenty-first century: economic injustice, which is the reason why at least 30,000 people die of starvation and other poverty-related diseases every day, and ecological destruction, which may well cause far greater death and destruction among future generations;

- become aware, again, of many people's enormous longing to know more about God in many secular and multi-religious contexts, the increased zeal for Christian education and the longing, in many parts of the world, for more opportunities to study theology;

- $\quad$ share in the joys, the difficulties and immense sorrows of the struggle for the survival and renewal of institutions of theological education in countries that are facing a dramatic growth of Christian churches and/or that are affected by the aftermath of natural disasters and major destruction of existing institutions of theological education (such as in Myanmar and China);

- celebrate the diversity of approaches to theological education and the commitment of many theological educators and regional associations of theological education around the globe to improving theological education and faculty development, thus contributing to the integral quality of life in its material and spiritual, physical and intellectual, moral and aesthetic, personal and communal, natural and cultural dimensions;

- share promising examples of new developments and models in theological education (such as the planning for a new centre of excellence in theological education and research in Asia), a variety of 
new ways of doing theological education in close contact with attempts to empower marginalised groups in India, new forms of teaching Ecumenics in distant learning courses, and many other initiatives.

\section{Challenges}

In deepening our insights and perspectives we became aware of a number of crucial and fundamental challenges that theological education systems face today:

- There is an immense need in many churches in the southern hemisphere and in Eastern Europe for more scholarships at postgraduate level - that is, more need for study programmes at Master's and Doctoral level;

- There are regions and countries in which the institutional capacities of theological education need to be strengthened and built up as a matter of urgency in order to answer the needs of rapidly growing churches;

- There are regions in which the creation or reshaping of regional centres of excellence in theological education is imperative;

- $\quad$ There are urgent needs for new curriculum developments that can meet the challenges of marginalised groups and/or new issues such as HIV/AIDS, ecotheology, bioethics and interreligious dialogue; without these, the churches cannot gain sufficient competence to develop and communicate their own positions;

- In a number of countries and traditions, there is still an immense need to strengthen the role of women in theological education;

- Better resources are needed for teaching ecumenism, ecumenical missiology, and interfaith dialogue in many places that, to date, have had no access to any means of teaching ecumenism;

- Some interdenominational colleges and centres of excellence in theological education are finding it more difficult than ever before to become financially selfreliant and viable;

- Many churches and funding organisations in developmental work still do not give proper attention to theological education in their budget plans; 
- In many regions, there has been a massive increase in the number of new colleges and bible schools, most of which have had no experience of, or connection to, theological education proper or the organised ecumenical movement;

- The international lobby for promoting and funding programmes of ecumenical theological education has remained small in WCC member churches and many funding agencies;

- The globalisation of the economy and the continuous brain drain of highly trained theologians from countries in the southern hemisphere to countries in the northern hemisphere exacerbates the problem of glaring discrepancies in the availability of proper expertise and library resources for theological education;

- The rapidly changing political scenarios in many national situations, as well as the global relations between Christianity and other world religions, demand stronger commitment to, and expertise in, new frontiers of theological discourse, such as inter-faith dialogue, bio-ethics, ecological ethics, and communication ethics than theological institutions can presently provide;

- The resurgence of religious fundamentalisms and exclusive denominationalism as counter-movements to the pressures of globalisation demand an ever deeper commitment to ecumenical theological education by all participants, despite the dwindling of funds and financial resources;

- There is an urgent need to educate future church leaders in a higher ecumenical consciousness. The changing ecclesial landscape in global Christianity also demands the creative development of new and more inclusive ecumenical networks for theological education. ${ }^{3}$

It is within this global picture of theological education that I reflect on the major challenges for African women theologians in theological education (1989-2008). Going back to 1989, when the Circle of Concerned African Women Theologians (hereafter the Circle) was launched in Ghana, I identified four major challenges that the African women theologians who are members of the Circle have had to contend with and that still exist. These are: (1) re-defining the identity of African women theologians; (2) encouraging more women to study theology and be on the permanent staff; (3) inclusion of African women's theology in the theological curriculum; and (4) 
collaboration with male theologians. As Oduyoye has pointed out, there are many Africas, which is why this article is mainly based on my own social location. I am an African woman whose theological education has only been through state universities; I benefited from the World Council of Churches Programme on Theological Education scholarship fund for women without having to obtain permission from my Presbyterian church in Malawi; I taught theology in an ecumenical environment for twenty-four years, in five state universities in three countries in southern Africa (Malawi, Namibia and South Africa); I have been a member of the Circle of Concerned African Women Theologians since its inception in 1989; and I coordinated the Pan African Circle from 2002 to 2007. It is this background that will mainly influence my analysis of the challenges that African women theologians face in theological education in Africa. I also realise that some of the issues raised affect all women globally, although in different ways. Before turning to the challenges facing African women in theological education, I need to start by making a few introductory remarks about the Circle.

\section{The Circle: introductory remarks}

The Circle is a community of African women theologians who come together to reflect on what it means to them to be women of faith within their experiences of religion, culture, politics and social-economic structures in Africa. "The Circle seeks to build the capacity of African women to contribute their critical thinking and analysis to advance current knowledge using a theoretical framework based on theology, religion and culture. It empowers African women to actively work for social justice in their communities and reflect on their actions in their publications." 4 The inspiration of having a Circle is attributed to Mercy Amba Oduyoye, who was the founder of the Circle.

From the outset, the Circle was inclusive in its membership and in the type of theology produced. African Women were defined as women who belong to diverse classes, races, cultures, nationalities and religions found on the African continent (Oduyoye, 2001b:10) and in the diaspora. This also meant bringing together women from the different religions in Africa to reflect on theology. African women have diverse experiences of patriarchal oppression in religion and in society. The theologies that African women write about reflect this diversity. What is important is that African women theologians are united in protesting against patriarchy.

Since its launch in 1989, the Circle has had three Pan-African conferences, each focusing on a particular theme that reflects the issues that African women theologians are concerned about. In 1996, the second Pan- 
African Conference took place in Nairobi, Kenya with the theme "Transforming Power: Women in the Household of God." This theme enabled the Circle to engage with the question: what does it mean for African women to be the church? The third Pan-African Conference took place in Addis Abeba, Ethiopia, in August 2002 with the theme "Sex, Stigma and HIV and AIDS: African Women Challenging Religion, Culture and Social Practices." Through this theme, African women highlighted the role played by sacred texts, the faith communities and African culture in both the fuelling and prevention of HIV and AIDS as it affects African women. The Circle's fourth Pan-African Conference took place in Yaoundé, Cameroon, in September 2007, with the theme: "The Girl Child, Women, Religion and HIV and AIDS in Africa: a Gendered Perspective." The highlight of this conference was the realisation that women alone cannot stop the spread of HIV in Africa. It emphasised the importance of a community approach in preventing HIV. It was the focus on identifying liberating masculinities that made this conference unique. I now turn to the challenges faced by African women theologians in theological education.

\section{The challenge of re-defining the identiry of African women theologiens}

The question: "Who is an African woman theologian?" has haunted the Circle from its inception. When the Circle was first established, one of its priorities was to identify women in theological institutions - the aim was to work together as a community of women so that African women could produce their own theology, a theology that seeks the liberation of women from oppression and discrimination. Circle members were mandated to contribute their unique voice to the continental and global theological voice on issues relating to women. Since then, the criterion for membership to the Circle has been writing and publishing theological literature. Nevertheless, the Circle did not want to limit the production of its theology only to those who reside in theological institutions. From the beginning it sought to be inclusive in its style of work. This meant working with women from outside the disciplines of theology and religion (but within the academy). It has also meant the inclusion of women who, for various reasons, ended their theological education at certificate, diploma and first-degree level and who are working in the church or have moved on to further their education in other disciplines outside theology and religion. Then there are those who are interested in issues that interface culture, religion and women in Africa, but who do not have any theological background. ${ }^{5}$ This is why the Circle claims that "elitism is not our way of life" (Oduyoye 2001a:34). It is about doing theology in the community of women in the academy and in the 
communities of faith. It is also about acknowledging the community of women who share their knowledge with researchers.

As noted from the Circle's vision and mission, ${ }^{6}$ research, writing and publishing on religion and culture from an African women's perspective forms the Circle's "core business". It is what distinguishes the Circle from other women's organisations and movements in Africa. However, the reality is that writing for publication presupposes that one has skills to do research, to theologically reflect on the information and to write well enough for publication. A look at the Circle membership list $^{7}$ and the quality of Circle books has shown that only a few Circle members have the capacity to write quality articles and books for publication. The Circle has noted this need for skills. As a result, at all its Pan-African conferences, training in the skills needed to write for publication is given priority.

The Circle has also used its partnership with other organisations as an opportunity to improve its members' research and writing skills. For example, between 2002 and 2007, the Circle formed partnerships with Yale University Divinity School (hereafter YDS) and Yale School of Public Health, together with Yale University's Centre for Interdisciplinary Research on AIDS (hereafter CIRA) to offer fellowships to African women theologians who were in the process of theologically reflecting on HIV and AIDS. ${ }^{8}$ In total, twelve Circle members have benefitted from spending four to nine months at Yale University as Faith fellows in the field of research that deals with gender, faith and HIV and AIDS. ${ }^{9}$ This partnership gave Circle members (the majority of whom are in theological education) the opportunity to use public health and theological methodologies to conduct field research in the area of gender, faith and HIV and AIDS. Most importantly of all, the time spent at Yale University gave Circle members access to resources that are not always available in many African countries. The research generated has/will result in quality articles published in international academic journals and chapters in academic books. The African women theologians who constitute the Circle have continued to seek a partnership of equals with other institutions with a view to promoting joint projects.

Furthermore, the Circle formed partnerships with the Ecumenical HIV and AIDS Initiative in Africa, World Council of Churches (hereafter, EHAIA) in 2006 in order to equip the church in Africa to be competent to deal with issues relating to HIV and AIDS. From 2003 to 2007, the Circle and EHAIA organised joint writing workshops and consultations in Moçambique and Angola (in 2003 and 2004); and in Benin, Rwanda, Botswana, South Africa, Kenya and Nigeria (in 2006 and 2007). It is through this partnership that the 
Lusophone Circle has managed to write and publish its ever first book (Pereira \& Cherinda 2007). The Circle's partnership with EHAIA also gave the Circle an opportunity to evaluate the quality of its research and writing. In 2006, EHAIA sponsored Musa Dube to evaluate the work of the Circle on HIV and AIDS. The report (Dube 2006) was presented at the Circle EHAIA 2006 Consultation held in Johannesburg. This report showed the gaps in the Circle's research and writing in the areas of gender, faith and HIV and AIDS in Africa. Future Circle researchers have thus been given direction as to which themes they need to emphasise.

The Circle's association with EHAIA highlighted, for me, some of the challenges faced in Lusophone Africa (Angola and Moçambique), a region where there are very few women in theological education. In the case of Moçambique, EHAIA sponsored the Circle to run workshops through the office of the General Secretary of the Christian Council of Churches in Moçambique. Over a period of five years, it became clear to me that, unless Circle members were equipped with higher theological education, it would be difficult to achieve the goals of the Circle in Lusophone Africa.

From my perspective, the real struggle that the Lusophone Circle has epitomised for the Circle is about the identity of African women theologians against the desire to be inclusive in our definition of who is an African woman theologian. While the Circle does not want to limit itself to the academy, the core mission of the Circle as described in this article opens itself to the charge of elitism. Tinyiko Maluleke, a prominent South African theologian and one of the few African male theologians who has taken the contributions of the African women theologians seriously, has made a profound critique of the Circle's selfdefinition. I want to quote Maluleke at length here to highlight his challenge to the Circle. He argues that:

My sense is that, although the Circle of Concerned African Women Theologians is, in reality, a circle of a higher class of women (and this holds true for chapters of the Circle all over the continent), this reality is not consciously foregrounded in the Circle's self-definition. Within South Africa, my impressions and observations have been that the Circle has become paler and whiter by the year, perhaps because in South Africa the class best positioned and therefore most able to execute the writing, speaking conferencing and publishing aims of the Circle are women of a paler shade. There is no doubt in my mind that the same situation obtains in chapters elsewhere on the 


\begin{abstract}
continent, except that power dynamics may not necessarily be displayed in skin colour. To a certain extent, the "Circle ideology" - to the extent that it does not foreground these kinds of differences overtly and boldly - is an ideology of exclusion. That exclusion is accomplished by means of 'imperial' inclusion of one and all - an ideology that denies difference (2001:248-249).
\end{abstract}

Maluleke's critique of the Circle's self-definition should make the Circle either re-define its core mission and vision or revisit its definition of who is a theologian and who therefore can become a member of the Circle. The Circle is between a rock and a hard place in that, by definition, as a liberation movement it would not choose to discriminate against other African women, who, although they consider themselves theologians, are unable to fulfil the aims of the Circle and yet would like to remain members of the Circle. Indeed, the Circle's very existence is a protest against exclusion and discrimination in faith communities and society as a whole. The Circle does not deny that there are differences between its theologians. It is for these reasons that the Circle also takes seriously the Circle's mentorship programme of African academics who are seasoned researchers; this is also why it is prepared to mentor those who have not published (by co-publishing articles and/or coediting academic books). Some examples of where such mentoring takes place are: the Pietermaritzburg Circle at the University of KwaZulu-Natal in South Africa and the St Paul's Circle at the St Paul's University, Limuru, Kenya. The quality of books and articles that have come from these two centres testify to the success of the mentoring programme. It has become the responsibility of current Circle leaders to develop the Circle mentoring programme in all Circle chapters.

The challenge of empowering women to study theology and teach in theological institutions

As a protest movement against any form of exclusion and discrimination, and a promoter of fullness of life as intended by God, the Circle seeks to increase the number of women studying and teaching theology. African women who are in theological education are well aware that the reluctance on the part of some churches to send women for theological education, or the reluctance of some seminaries to admit women as students, is a theological reluctance. This is why African women theologians have generated many wellresearched articles in an attempt to engage the churches on their understanding of the humanity of women and the African understanding of the 
church. ${ }^{10}$ African women theologians have worked with some programmes of international faith organisations such the World Council of Churches, the World Alliance of Reformed Churches, the Lutheran World Federation and the Council for World Mission to produce resources for the churches in Africa that promote the building of a community of women and men in the churches. It was as a result of the Circle's own research and the joint work with the abovementioned institutions that it has been established that there are two areas of challenge: the first is connected to the enrolment of women to study theology, and the second is connected to the recruitment of women on the staff of theological institutions.

Challenges that are linked to the enrolment of African women to study theology include the following: (a) there are still only a few women in theological education in Africa because the missionaries who initially came to Africa linked the study of theology with the ordained ministry. Although the mission churches became autonomous from their mission heritage, they continued with the policy of linking theological education to the ordained ministry. By doing this, theological education is out of reach for the majority of African women to this day; (b) in line with point (a), some churches have allowed the enrolment of a few women in theological education for work among women. The painful part for women is that the men and women who enrol for theological education study the same content but, in some cases, receive different qualifications. In other cases, they get the same qualification but are assigned to different positions in the church. Women are made to work under the leadership of their male classmates; (c) there are a few women who study theology for the ordained ministry. While some churches have accepted the ordination of women, they nevertheless sponsor very few women to study theology; (d) compared with the enrolment of women in seminaries, there are many lay women in theological education - these women are studying through theological education by extension or theological departments/schools in state universities. The majority of these women are not recognised in their churches since they were not sent by the church to study theology; (e) many women who want to study theology through state universities and who may have the approval of their churches nevertheless fail to meet the entrance qualifications because they did not receive a full school education. This is connected to the cultural perception that when families do not have enough money to educate all their children, priority is given to the boy children because they will grow up to be breadwinners, while girl children will be married off to men who will support them; (f) there are women who do not want to study theology because they are not sure of employment opportunities outside the church, since many people still have the perception that theology is for ordination purposes only; $(\mathrm{g})$ scholarships too have an age limit, which works against many women who postpone their studies until later in life so that they can first have children and raise a family. 
By the time they plan to go back to further their theological studies, they have already past the qualifying age for funding. Thus, although they are able to secure a place for further studies in theology, they are deemed to be too old to qualify for a scholarship; (h) while a donor may have a policy to grant a certain percentage of the scholarships to women, experience in Africa has shown that the biggest problem is to get the approval of church leaders to endorse the application form of a woman who wants to study theology, but who was not sent by her church. Theological education thus remains the privilege of those who have been chosen by the churches to study theology. But theological education must be for all the people of God. While some funding institutions have recognised the receiving institution as the only authority to endorse a student's application for scholarship, this has been the exception and not the rule with most funding agencies.

In relation to the recruitment of women on the staff of theological institutions, the research of the Circle and its partners has shown that: (a) there are more theological institutions in Africa that have no women on its staff than those that recruit women; (b) among the few women who are recruited to teach in theological institutions in Africa, the majority are teaching non-theological subjects. This means that only a few lay/ordained women teach theological subjects; (c) the majority of lay women from university, theological schools or departments who are invited to teach theological subjects either do so on a part-time basis or on limited-term contracts. The disadvantage of not being on permanent employment is that one is not qualified to go on sabbatical leave (and thus unable to concentrate on research and publication). And without publishing, a staff member will not progress academically.

It is within this scenario that African women theologians who are in theological education see their role as educators of the church leadership and lay people about the ordained and lay ministry of women. They encourage many women to enrol in theological education even if their churches do not ordain women because theological education is not only for the ordained ministry, but for all the people of God. They play an advocacy role for the provision of good accommodation that is conducive to the process of learning for female theological students. They also play an advocacy role by connecting African women with funding agencies that are interested in promoting the theological education of African women. ${ }^{11}$

African women theologians who are in theological education work with theological institutions to promote the employment of African women as permanent lecturers in theological disciplines. This has proved to be a very frustrating exercise if the head of the institution does not share the vision of women empowerment in theological institutions. African women theologians write about such experiences so that they can theologically reflect on what is going on and thereby gain collective wisdom from other sisters who may 
have gone through a similar experience and managed to overcome such obstacles. The Circle mentoring programme works well not only in the context of student and staff relationship, but also among staff members. Experienced publishers pair up with emerging scholars to transfer not only research and publishing skills, but also the entire mentoring programme.

The challenge of engendering the Theological Education Curriculum in Africa

The Circle also encourages the teaching of gender issues in the theological curriculum. This means making gender a concept in theological analysis. A gendered approach to theology refers to exposing the injustices that exist in the church, culture and the bible in relationships between men and women. It acknowledges that human beings construct culture, therefore cultural practices in the bible and in our own cultures should not be confused with the will of God. It highlights the importance of acknowledging that both men and women are created in the image of God. The process of change requires an analysis of the African worldview and how people's identities are constructed (Phiri 2002).

The need for mainstreaming gender in theological education is a global one and has been well articulated in a number of theological conferences and by a number of scholars. A few examples from the international conferences, seminars and working groups will suffice to show the global awareness of the problem. In 1997, I was part of the World Conference of Associations of Theological Institutions in Indonesia, which highlighted the fact of male domination in the theological curricular, in staff quotas, and student numbers; the same conference also called on the need to redress the situation. I was also present when these same sentiments were echoed at the Lutheran World Federation (LWF) Global Consultation on Theological Education in Rome in 1999 and at the PTE of the WCC Consultation on "Viability of Theological Education and Ministerial Formation in Africa" in Kuruman, South Africa, in 1995 (Phiri 1995). The Lutheran World Federation took the lead at a global level to begin the process of engendering the theological education by organising a consultation on "Engendering Theological Education for Transformation", held in Montreux, Switzerland, 4-8 November 2001. The report of this consultation has been widely circulated to stimulate further discussions on engendering theological education.

It was in this global context and taking its cue from the ETE of the 2002 World Council of Churches Conference on "The Journey of Hope Continued" that the Circle embarked on the process of engendering the Theological Education Curriculum project sponsored by the Ecumenical Theological Education of the World Council of Churches. Workshops were held in Johannesburg in 2004 and in Benini in 2005 to work on engendering 
the theological curriculum in Anglophone and Francophone Africa. This project resulted in the production of handbooks to be shared with theological institutions in Africa. ${ }^{12}$ However, the Circle's greatest challenge has been the circulation of its literature to the theological institutions in Africa and making sure that the books are being used to contribute to the shaping of religious leadership on the continent.

Conscious of the fact that most theological institutions in Africa follow a curriculum that reflects the old European norms of classical religion and theological courses, the Circle members who are at St Paul's University, University of KwaZulu-Natal and the Institute of Women, Religion and Culture, Trinity, have developed well-stocked libraries to sustain undergraduate and postgraduate studies in gender and religion. As of 2008, it is only University of KwaZulu-Natal that offers full degrees at honours', Master's and PhD level, with the words "Gender and Religion" being written on the certificate. While many students would like to enrol in this programme because they know that the contents of the course will be of benefit to the church in Africa, some students have also expressed the fear that their bishops would not approve of their certificate showing Gender and Religion next to the name of the degree (as is done at the University of KwaZuluNatal). ${ }^{13}$

The engendering of the theological curriculum is done at three levels. The first level is to advocate for the inclusion of gender issues in all disciplines and in each course. Secondly, it means offering gender courses as electives at introductory, intermediate and advanced levels. The third level means offering a whole programme in gender and theology/religion, with a designated chair at postgraduate level. This means that, when a post is advertised for gender and religion/theology, it specifies that the incumbent will be responsible for the coordination of the engendering of the theological curriculum as well as giving leadership to the gender and religion postgraduate programme. In May 2008, such a chair was created in the School of Religion and Theology, at the University of KwaZulu-Natal. ${ }^{14}$

\section{The challenge of collaborating with African male theologians}

African women theologians working in theological education are aware that the success of the engendering of the theological curriculum is connected to their success in collaborating with African male theologians in the academy and the churches. From the outset, therefore, the Circle did not introduce African women's theology as a replacement for African theology, but as an addition to the missing voice in African theology. Hence, it is with gratitude that the Circle acknowledges those African male theologians who have walked alongside the Circle to affirm its voice. Those who have been overt in their support of the work of the Circle are many, but at the risk of leaving 
some names out, I would want to especially acknowledge the following: John Pobee who, through PTE and ETE, has been in the forefront in seeking out African women and encouraging them to study theology. I am one of his products. Even in his writings, he has encouraged other men to take seriously the emergence of African Women's Theology. In the Ecumenical Review of July 2001, whose theme was "Transforming Ecumenism in Africa in the 21st Century", a number of articles paid homage to the contribution of the Circle in ecumenical formation in Africa. Some examples of African male theologians who spoke positively of the contribution of the Circle to theological formation were Sam Kobia (2001:295-305) and, as mentioned already, John Pobee (2001:319-332).

Simon Maimela is another African male theologian, who used his space at the University of South Africa (Unisa) to offer courses that included the work of African women theologians. This cumulated in the book that he co-edited with Adrio König, entitled: Initiation into theology: the rich variety of theology and hermeneutics. This edition includes articles by Christina Landman and Mercy Oduyoye (on African Women's Theology and African Women's Hermeneutics respectively). John Mbiti also dialogues with African women theologians. In fact, it has now become fashionable to include articles by African women theologians in any edited book that is penned by African male theologians. However, it is Tinyiko Maluleke (1997, 2001), Laurent Magesa (2005) and Ogbu Kalu (2006) who have, in particular, heeded the call of African women theologians for the need for serious and deliberate critical engagement with African women theologians in theological education.

The current emergence of articles written by African male theologians on issues on masculinities ${ }^{15}$ are other significant examples of African men and women theologians collaborating in teaching, research and writing on gender issues. Discussions on masculinities took centre stage at the Circle 2007 Pan-African Conference when, in partnership with the World Council of Churches (EHAIA), it organised two panels for the Circle to dialogue with African male theologians on the topic of "Liberating Masculinities and Combating HIV \& AIDS". ${ }^{16}$ What is important is that such presentations and discussions form the resources that African women theologians would like to see being used by students and staff in theological institutions.

The biggest challenge of the Circle remains to motivate more male students and staff of theological institutions to be in dialogue with the literature produced by African women theologians.

\section{Conclusion}

After some nineteen years of the Circle's existence, African women theologians have gained recognition in the theological arena at both a local 
and global level. The Circle has achieved its objective of increasing the number of theological publications for the academic use of theological institutions in Africa. It is also participated in the theological debates of the northern hemisphere through its partnership of equals with theological institutions. Its ethos of being inclusive in: (1) its definition of African women theologians; (2) its promotion of an increased enrolment of female students and employment of more female staff; (3) its contribution to the process of engendering the theological curriculum in Africa; and (4) its overt efforts to promote collaboration with African male theologians has gone a long way to show that the Circle is built firmly on the concept of community. There are many theological institutions that fear the work of African women theologians simply because they misunderstand what is meant by gender analysis in theological curriculum. This challenge can only be dealt with through a balanced education of all the people of God. We need to educate the churches and theological institutions locally and globally, so that the community of both women and men work together to decide on the type of theology that should be taught in the theological institutions. If indeed the church acknowledges that God gives gifts to both women and men for the common good of the church, then it needs to transform itself to support in word and action the theological education of both men and women. This requires the realisation that, according to the signs of our times, theological education should no longer be seen as training solders of Christ whose task is to ward off heresy, but servants of Christ: people who are willing to build a community of women and men.

\section{Works consulted}

Dube, Musa W 2001. Fifty years of bleeding: A storytelling feminist reading of Mark 5:24-35, in Dube, M W (ed.) in Other ways of reading: African women and the Bible, 26-49. Atlanta: SBL.

Dube, Musa W 2006. Circle of life: African women theologians' engagement with HIV\&AIDS. Unpublished Report. University of Botswana.

Haddad, Beverley 2001. Engendering theology: What does it entail? Paper presented at the Lutheran World Federation Consultation "Engendering Theological Education for Transformation" Montreux, Switzerland, 4-8 November.

Kalu, Ogbu U 2006. Daughters of Ethiopia: Constructing a feminist discourse in ebony strokes, in Phiri, I A \& Nadar, S (eds.), African women, religion and health: Essays in honour of Mercy Amba Oduyoye, 261-279. Maryknoll/Pietermaritzburg: Orbis/Cluster.

Kanyoro, Musimbi R A 2002. Beads and strands: Threading beads to her story in the Circle, in Phiri, I A Govinden, D B \& Nadar, S (eds.), 
Her-stories: Hidden histories of women of faith in Africa, 15-38. Pietermaritzburg: Cluster.

Kobia, Sam 2001. Denominationalism in Africa: The pitfalls of institutional ecumenism. The Ecumenical Review 53(3), 295-305.

Landman, Christina 1999. African women's theology, Maimela, S \& König, A (eds.), Initiation into theology: The rich variety of theology and hermeneutics, 137-140. Pretoria: Van Schaik.

Magesa, Laurent 2005. The challenge of African women defined theology for the $21^{\text {st }}$ century, in Ndung'u, N W \& Mwaura, P N (eds.), The challenges and prospects of the church in Africa: Theological reflections of the $21^{\text {st }}$ century, 88-101. Nairobi: Paulines Publications Africa.

Maimela, Simon \& König, Adrio (eds.) 1999. Initiation into theology: The rich variety of theology and hermeneutics. Pretoria: Van Schaik.

Maluleke, Tinyiko Sam 1996. Recent developments in the Christian theologies of Africa: Towards the twenty-first century. Journal of Constructive Theology 2(2), 33-60.

Maluleke, Tinyiko Sam 1997. The "Smoke screens" called black and African theologies: The challenge of African women theology. Journal of Constructive Theology 3(2), 39-63.

Maluleke, Tinyiko Sam 2001. African "Ruths", ruthless Africas: Reflections of an African Mordekai, in Dube, M W (ed.), Other ways of reading: African women and the Bible, 237-252. Atlanta: SBL.

Mbiti, John S 1999. African theology, in Maimela, S \& König, A (eds.), Initiation into theology: The rich variety of theology and hermeneutics, 141-157. Pretoria: Van Schaik.

Mombo, Esther 2000. Theological education in Africa. Ministerial Formation 89, 39-45.

Njoroge, Nyambura Jane 1996. Groaning and languishing in labour pains, in Kanyoro, M R A \& Njoroge, N J (eds.), Groaning in faith: African women in the household of God, 5-7. Nairobi: Acton.

Njoroge, Nyambura Jane 2001. Talitha Cum! To the new millennium: A conclusion, in Njoroge, N J \& Dube, M W (eds.), Talitha Cum: Theologies of African women, 252-253. Pietermaritzburg: Cluster.

Oduyoye, Mercy Amba 1999. African women's hermeneutics, in Maimela, S \& König, A (eds.), Initiation into theology: The rich variety of theology and hermeneutics, 359-371. Pretoria: Van Schaik.

Oduyoye, Mercy Amba 2001a. The search for a two-winged theology: Women's participation in the development of theology in Africa, in Oduyoye, M A \& Kanyoro, R A (eds.), Talitha Cumi! Proceedings of the convocation of African women theologians 1989, 31-56. Second Edition. Accra-North: Sam-Woode. 
Oduyoye, Mercy Amba 2001b. The Convoking The Circle of Concerned African Women Theologians, in Oduyoye, M A \& Kanyoro, R A (eds.), Talitha Cumi! Proceedings of the convocation of African women theologians 1989, 10-30. Second Edition. Accra-North: Sam-Woode.

Oduyoye, Mercy Amba 1997. Transforming power: Women in the household of God. Proceedings of the Pan-African Conference of the Circle of Concerned African Women Theologians. Accra-North: Sam-Woode.

Pereira, Maria Victoria \& Cherinda Felicidade (eds.) 2007. Tempo De Mudar, Tempo De Agir: Mulheres reflectem teológicamente sobre a problemática do HIV/SIDA. Pietermaritzburg: The Circle of Concerned African Women Theologians.

Phiri, Isabel Apawo 1990. Women in theological education in Malawi. Women and Theology: Ministerial Formation 48, 14-19.

Phiri, Isabel Apawo 1995. Women, church and theological education. Ministerial Formation 17, 39-43.

Phiri, Isabel Apawo 1996. Marching, suspended and stoned: Christian women in Malawi, in Ross, K (ed.), God, people and power in Malawi: Democratisation in theological perspective, 63-105. Gweru: Mambo.

Phiri, Isabel Apawo 1997a. Women Presbyterianism and Patriarchy: Religious experiences of Chewa women in Central Malawi. Blantyre: CLAIM.

Phiri, Isabel Apawo 1997b. Doing theology in community: The case of African women theologians in the 1990s. Journal of Theology for Southern Africa 99, 68-76.

Phiri, Isabel Apawo 2000. Empowerment of women through the Centre for Constructive Theology. Ministerial Formation 89, 46-56.

Phiri, Isabel Apawo 2005a. Life in fullness: Gender justice: A perspective from Africa. Journal of Constructive Theology 8(2), 69-82.

Phiri, Isabel Apawo 2005b. The Circle of Concerned African Women Theologians: Its contribution to ecumenical formation. The Ecumenical Review 57(1), 34-41.

Phiri, Isabel Apawo \& Nadar, Sarojini (eds.) 2005. On being church: African women's voices and visions. Geneva: World Council of Churches Publications.

Phiri, Isabel Apawo \& Nadar, Sarojini 2006. What's in a name? Forging a theoretical framework for African women's theologies. Journal of Constructive Theology 12(2), 5-24.

Pobee, John S 2001. Ecumenical formation in the service of a renewed church. The Ecumenical Review, 53(3), 319-332. 


\section{Endnotes}


1 A paper presented at the Christian Theological Seminary Saltsburg lecture, Monday September $15^{\text {th }} 2008$

2 Isabel Apawo Phiri is a Professor of African Theology in the School of Religion and Theology at the University of KwaZulu-Natal, Private Bag, X01, Scottsville, 3209, Pietermaritzburg, South Africa. Email: phirii@ukzn.ac.za. She was the General Coordinator of the Circle of Concerned African Women Theologians from 2002 to 2007.

3 This section is taken from WOCATI Press Release, "THEOLOGICAL EDUCATION: A RADICAL REAPPRAISAL". A Conference of Strategic Importance for the Ecumenical Theological Education for Christianity in the 21 st century. This document is found on the websites of WCC/ETE and WOCATI (www.oikumene.org and www.wocati.org).

4 These are the objectives of the Circle as reflected in the Circle draft constitution, 2007.

5 The 2007 draft constitution of the Circle recognises the two levels of African women theologians when it states: "The membership of the Circle shall be individual African women theologians who are committed to research, writing and publication. A woman theologian shall be defined as a woman who has studied religion and/or theology and religion at university departments, schools or faculties of Religious Studies/theology or in faith-based theological institutions. A woman theologian shall also include a woman of faith from other disciplines who share the concerns of the Circle."

6 The mission of the Circle is to undertake research, writing and publishing on African issues from women's perspective. The vision of the Circle is to empower African women to contribute their critical thinking and analysis with a view to advancing current knowledge. Theology, religion and culture are the three chosen foci, which must be used as the framework for Circle research and publications.

7 In 2007 the Circle had 660 registered Circle members divided as follows: Anglophone members 522, Francophone members 83, and Lusophone members 55.

8 The agreement for the Circle partnership with YDS and CIRA was established during the Circle leadership of Dr Musimbi Kanyoro (1996 to 2002). It was implemented during my period of leadership of the Circle, 2002-2007. The Circle worked with Prof Letty Russell, Dr Shannon Clarkson, Prof Margaret Farley and Dr Kari Hartwig to make this dream a reality.

9 The list of the faith fellows include: Fulata Moyo (Malawi); Sylvia Amisi (Kenya); Vuadi Vibila (Democratic Republic of Congo); Anne Nasimiyu-Wasike (Kenya); Dorothy Ucheaga (Nigeria); Teresa Tinkasimiire (Uganda); Constance Shisanya (Kenya); Isabel Phiri (Malawi); Dorcas Ankitunde (Nigeria), Hazel Ayanga (Kenya), Lillian Siwila (Zambia) and Bongiwe Dumezweni (South Africa).

10 See the Circle publication Phiri and Nadar (2005).

11 The Ecumenical Theological Education of the World Council of Churches in Geneva, the EMW in Germany, the Reformed Churches in the Netherlands and the Yale Divinity School in the USA are some of our partners in the theological education of African women.

12 Publications still in progress include: Phiri Isabel Apawo and Musa W. Dube (eds.) The engendering theological curriculum handbook. Pietermaritzburg: Cluster Publications. Already published: Yinda Helene et Ngalula J. Changer la Theologie, Transformer la Societe. Programme d'education et formation theologique de genre et feminisme. Yaoundé-Bafoussam. Editions Cle et Cipcre 2007. See also Phiri (2005b).

13 For example, the named degrees show as follows: Bachelor of Theology (honours) (Gender and Religion); Masters in Theology (Gender and Religion) and Doctor of Theology (Gender and Religion).

14 Dr Sarojini Nadar is the first Circle member to be appointed in a permanent position as the coordinator of a postgraduate programme in Gender and Religion.

15 See the Journal of Constructive Theology 12/1, (2006) and 14/1 (2008), which is dedicated to a discussion about issues on masculinities (written by African male theologians).

16 The titles of the presentations were as follows: HIV and AIDS and Masculinities (Dr Ezra Chitando); The Bible and Manhood in African Culture (Prof Tinyiko Maluleke); Church and Masculinity (Prof Ka Mana); Youth and Masculinity (Mr Zeferino Teka); Modern Masculinities (Dr Manoj Kurian); Colonial/Rural-Urban Masculinities (Rev Dinis Matsolo); Amnon, Son of David: Subverting Biblical Masculinity (Prof Gerald West); ANARELLA and Masculinities (Rev. Johannes Heath). 